Вип. 2, 2019

УДК: 005.35:334

H. V. Lema, I. B. Oleksiv, V. Yu. Kharchuk, T. Yu. Lisovych

Lviv Polytechnic National University

\title{
CORPORATE SOCIAL RESPONSIBILITY AT EMERGING MARKET: UKRAINIAN DIMENSION
}

http://doi.org/

(C) Lema H. V., Oleksiv I. B., Kharchuk V. Yu., Lisovych T. Yu., 2019

Corporate social responsibility (CSR) is a concept, which is trending in different parts of the world. According to the academic literature there are differences in understanding of corporate social responsibility in economically developed markets (societies where stakeholder activism is well accepted) and emerging markets (economically driven). The idea of the current article is to research, whether companies from emergent markets are following their counterparts from well-developed markets in terms of CSR through studying CSR reports.

Key words: corporate social responsibility; social reports of enterprise; elements of corporate social responsibility.

\section{Formulation of the problem}

Today a great number of enterprises choose the course of their activity development in a way of involving a wide range of stakeholders. In such a case, enterprise strategy is usually built in a way of the acceptance of the principles CSR. CSR of modern enterprises is an important manifestation of the interaction of social and economic relations. Among Ukrainian enterprises, the promulgation of a nonfinancial report on CSR is quite popular. Such report enables stakeholders to familiarize with the interaction of enterprise with social actions. One of the drawbacks of report compilation on CSR of enterprise is the lack of clear structure. In addition to this, today there are no indexes or postulates for the evaluation of corporate social responsibility of enterprises. Thereby, the most enterprises report without keeping to the form. As a result of this, there exist complications in social reports analysis, since they are not compulsory. So, the formation of methodological recommendation which include the criteria, indexes and peculiarities of evaluation make it the most important duty for the enterprises in the process of the investigation of corporate social responsibility of national ones. The advantages of enterprises participation in social responsibility is the possibility of the expansion of the outlets, economizing of the resources while applying eco equipment in the process of manufacture, creating more working places, etc.

\section{Literature review}

In academic literature research connected to CSR at Eastern European countries are quite limited. However, there are some influential publications devoted to the issue. In particular, Elms (2006) analyzed the understanding of CSR in East European countries. Furrer et. al (2010) researched the differences in understanding of CSR in Eastern and Western European countries. Candidatu and Grigore (2009) analyzed the perception of CSR in Eastern European countries. Iankova (2008) analyzed the transformation of paternalistic concept into CSR concept in Eastern European countries. Strouhal et. al (2015) researched the link between CSR reporting and company performance in Estonia and Czech Republic as well as Vitezić (2011) researched the influence of CSR on financial performance of Croatian companies. Knez-Riedl (2004) researched importance of environmental issues in CSR of Slovenian companies. Ransburg and Mária Vágási (2007) researched acceptance of CSR standards by Romanian companies. Rogowski (2013) analyzed CSR related activities of Polish companies. Vlastelica et. al (2018) researched the influence of CSR on corporate reputation in Serbian companies.

CSR is as a construct of four aspects (Market place, Working place, Environment and Community) (Carrol, 1991). Currently only one publication was devoted to studying separate aspects of CSR construct at companies operating in the emergent markets (Vlastelica et. al 2018). 
The other issue important for the current research was identified in Elms, 2006. According to Elms, 2006 there two types of environments in relation to CSR issues. They are: economically driven societies or emergent markets and societies where stakeholder activism is well accepted or developed markets.

The current research will contribute to the academic debate in studying different aspects of CSR in Eastern European countries. The main idea of the project is to analyze whether companies operating in Ukraine, which belong to Ukrainian nationals are following the companies operating in Ukraine, which belong to multinationals in terms of implementation CSR standards.

\section{The purpose of the article}

The main idea of the project is to analyze whether companies operating in Ukraine, which belong to Ukrainian nationals are following the companies operating in Ukraine, which belong to multinationals in terms of implementation CSR standards.

From this idea the following research question arises: How the companies, which belong to Ukrainian nationals are following the companies, which belong to multinationals, in terms of considering CSR issues? In particular, what are the differences in consideration of different CSR aspects, such as Market place, Working place, Environment and Community (Carrol, 1991).

Therefore, the expected results of the research are the following:

1. To find out how the companies, which belong to Ukrainian nationals, are following the companies, which belong to multinationals, in terms of considering CSR issues. In particular, what are the differences in consideration of different CSR aspects, such as Market place, Working place, Environment and Community (Carrol, 1991).

2. To find out the differences in listed CSR aspects in the companies, which belong to Ukrainian nationals, and the international subsidiaries.

\section{Setting objectives}

The current research is based on qualitative analysis. It consists of the following steps:

1. Selection of the company samples. Two samples of companies submitting non-financial reports are going to be developed, which are the following: companies, which belong to Ukrainian citizens and companies, which belong to multinationals.

2. Selection of indicators (factors), which characterize four aspects of CSR structure (Market place, Working place, Environment and Community). Indicators (factors) are going to be selected basing on studying CSR reports.

3. Development of qualitative scale to evaluate the level of consideration of indicators (factors) in step two of the current method.

4. Comparison of non-financial reports submitted by Ukrainian companies and international subsidiaries operating in Ukraine using indicators and scale developed at steps 2 and 3 of the current methodology. Finding out the differences in CSR aspects in the companies, which belong to Ukrainian nationals, and the international subsidiaries.

\section{Results of the research}

1. Selection of the company samples. While creating the sample of companies operating in Ukraine the following requirements for selection of sample where used:

- Year of CSR report submission. The last year for, which CSR reports are available now, is 2017. Currently quite a limited number of Ukrainian companies submitted CSR reports for the year 2018. Thus, it was decided to use for the analysis the most recent CSR reports from the years 2016 and 2017.

- Type and structure of CSR reports. Other factor to influence the choice of company is the possibility to compare the structures of the formation of CSR reports. It turns out, that the companies under investigation follow the same structure of declaration of the information on their activity in CSR reports: economic, ecological and social results of the investigation. Such structure of the formation of CSR report meets the standards of GRI (Global Reporting Initiative: https:/www.globalreporting.org/resourcelibrary/ G3.1-Guidelines-Incl-Technical-Protocol.pdf.), ISO 26000 (AA1000 stakeholder engagement Standard 2011/ AccountAbility Stakeholder Engagement Technical Committee. - 2011. - 52 p.) and Form-10-k (https://www.investopedia.com/terms/s/sec-form-n-csr.asp), as well as the compamies which present their 
CSR report without following any standard. (see. tabl. 1). This way, we have formed two samplings out of suggested enumeration of the companies. Ukrainian companies belong to the first sampling, presented the following types of reports: 9 companies presented according to GRI standards, 4 - ISO 26000, 6 ones did not follow any standards. International subsidiaries which work at Ukrainian market belong to the second sampling, they have presented the following types of reports: 8 - GRI standard, 3 - ISO 26000, 3 - Form$10-\mathrm{k}$ and $1-$ do not follow any standard.

Table 1

Analyses of CSR characteristics of international subsidiaries and Ukrainian companies

\begin{tabular}{|c|c|c|c|c|c|c|c|c|c|c|c|c|c|c|}
\hline \multirow[b]{2}{*}{ № } & \multirow[b]{2}{*}{ Companies } & \multirow[b]{2}{*}{$\begin{array}{c}\text { CSR } \\
\text { report } \\
\text { standard }\end{array}$} & \multicolumn{3}{|c|}{ Market place } & \multicolumn{3}{|c|}{$\begin{array}{l}\text { Working } \\
\text { place }\end{array}$} & \multicolumn{4}{|c|}{ Environment } & \multicolumn{2}{|c|}{ Community } \\
\hline & & & 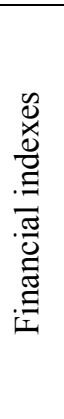 & 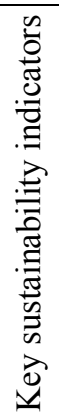 & 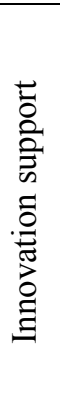 & 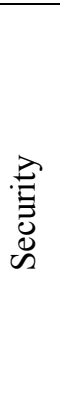 & 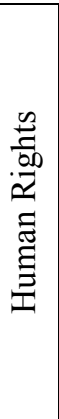 & 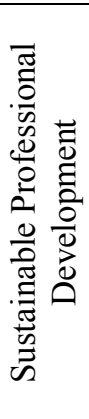 & 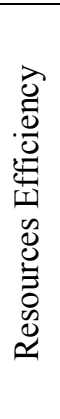 & 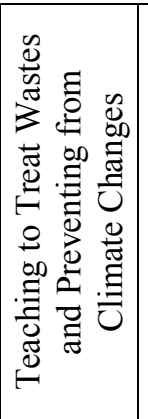 & 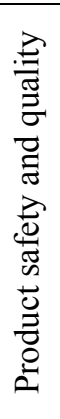 & 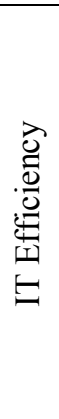 & 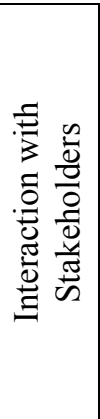 & 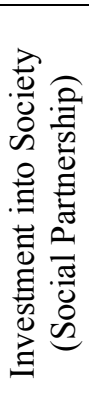 \\
\hline 1 & 2 & 3 & 4 & 5 & 6 & 7 & 8 & 9 & 10 & 11 & 12 & 13 & 14 & 15 \\
\hline \multicolumn{15}{|c|}{ International subsidiaries } \\
\hline 1 & Hewlett-Packard's & Form-10-k & + & + & + & + & + & + & + & + & + & + & + & + \\
\hline 2 & Coca-Cola Україна & Form-10-k & + & + & & + & + & + & + & + & + & + & + & + \\
\hline 3 & Sturbucks Corporation & Form-10-k & + & + & & + & + & + & + & + & + & + & + & + \\
\hline 4 & Adidas Group & GRI & + & + & + & + & + & + & + & + & + & + & + & + \\
\hline 5 & BMW Group & GRI & + & + & + & + & + & + & + & + & + & + & + & + \\
\hline 6 & Ernst\&Young Україна & GRI & + & + & & + & + & + & + & + & + & + & + & + \\
\hline 7 & Lifecell & GRI & + & & + & + & + & + & + & & + & + & + & + \\
\hline 8 & $\begin{array}{l}\text { McDonald's } \\
\text { Corporation }\end{array}$ & GRI & + & + & & + & + & + & + & + & + & + & + & + \\
\hline 9 & Nestle Ukraine & GRI & + & + & + & + & + & + & + & + & + & + & + & + \\
\hline 10 & Tiffany and Co & GRI & + & + & & + & + & + & + & & & & + & + \\
\hline 11 & $\begin{array}{l}\text { TОВ “КПМГ- } \\
\text { Україна” }\end{array}$ & GRI & + & + & & + & + & + & + & & + & + & + & + \\
\hline 12 & $\begin{array}{l}\text { ТОВ Ашан Україна } \\
\text { Гіпермаркет }\end{array}$ & ISO 26000 & + & & & + & + & + & + & + & + & + & + & + \\
\hline 13 & $\begin{array}{l}\text { TOВ Метро Кеш Енд } \\
\text { Кері Україна }\end{array}$ & ISO 26000 & + & & & + & + & + & + & + & + & + & + & + \\
\hline 14 & $\begin{array}{l}\text { ПрАТ Філіп Морріс } \\
\text { Україна }\end{array}$ & ISO 26000 & + & & + & + & + & + & + & + & + & + & + & + \\
\hline 15 & Honda Global & NS & + & + & + & + & + & + & & + & + & + & + & + \\
\hline \multicolumn{15}{|c|}{ Ukrainian companies } \\
\hline 16 & DTEK & GRI & + & & & + & + & + & + & + & & & + & + \\
\hline 17 & Soft Serve & GRI & + & + & & + & + & + & + & & + & + & + & + \\
\hline 18 & ТОВ “АТБ маркет” & GRI & + & & & + & + & + & & & + & & + & + \\
\hline 19 & \begin{tabular}{|l|} 
Концерн \\
“Галнафтогаз”
\end{tabular} & GRI & + & & & + & + & + & + & & & & + & + \\
\hline 20 & $\begin{array}{l}\text { Корпорація } \\
\text { "Оболонь” }\end{array}$ & GRI & + & & & + & + & + & + & + & + & & + & + \\
\hline 21 & $\begin{array}{l}\text { Миронівський } \\
\text { хлібопродукт }\end{array}$ & GRI & + & + & & + & + & + & + & + & + & & + & + \\
\hline 22 & Нібулон & GRI & + & & & + & + & + & + & & & & + & + \\
\hline 23 & Нова Пошта & GRI & + & & & + & + & + & + & & + & + & + & + \\
\hline
\end{tabular}


Continuation of Table 1

\begin{tabular}{|c|c|c|c|c|c|c|c|c|c|c|c|c|c|c|}
\hline 1 & 2 & 3 & 4 & 5 & 6 & 7 & 8 & 9 & 10 & 11 & 12 & 13 & 14 & 15 \\
\hline 24 & $\begin{array}{l}\text { ТОВ "Український } \\
\text { Рітейл" }\end{array}$ & GRI & + & + & & + & + & + & + & & & & + & + \\
\hline 25 & Biofarma & ISO 26000 & + & & & + & + & + & + & + & + & & + & + \\
\hline 26 & FerrexpoGroup & ISO 26000 & + & & & + & + & + & + & & & & + & + \\
\hline 27 & $\begin{array}{l}\text { Авіакомпанія } \\
\text { "Міжнародні } \\
\text { авіалінії України" }\end{array}$ & ISO 26000 & + & & + & + & + & + & & & + & & + & + \\
\hline 28 & ТОВ “Епіцентр-К” & ISO 26000 & + & & & + & + & + & & & & + & + & + \\
\hline 29 & Agrogeneration & NS & + & & & + & + & + & + & & & & + & + \\
\hline 30 & Roshen & NS & + & & & + & + & + & + & & + & & + & + \\
\hline 31 & WolWest Group & NS & + & & & + & + & + & + & & & & + & + \\
\hline 32 & Iнтерхім & NS & + & & & + & + & + & + & + & + & & + & + \\
\hline 33 & Компанія ТCO & NS & + & & & + & + & + & + & & & & + & + \\
\hline 34 & ПАТ “Укртелеком" & NS & + & & + & + & + & + & & & + & + & + & + \\
\hline
\end{tabular}

* Умовні позначення: GRI - Global Reporting Initiative; ISO 26000 - AA1000 stakeholder engagement Standard; NS- not specified.

Table 2

\section{CSR market place elements}

\begin{tabular}{|l|l|l|}
\hline № & \multicolumn{1}{|c|}{ Elements } & \multicolumn{1}{c|}{ Descriptions of Elements } \\
\hline 1. & $\begin{array}{l}\text { Work } \\
\text { Results(financial } \\
\text { indexes) }\end{array}$ & $\begin{array}{l}\text { Financial results are mostly presented in the form of more income (loss) and taxes. } \\
\text { Apart from this, the results of enterprise work represent the expenses on } \\
\text { investigations and development of enterprise activity. }\end{array}$ \\
\hline 2. & $\begin{array}{l}\text { Key sustainability } \\
\text { indicators }\end{array}$ & $\begin{array}{l}\text { National companies apply different financial indexes to characterize its activity, but } \\
\text { the divergent feature is the lack of system of key indexes of a sustainable } \\
\text { development, such as: business activity (revenues, income, sales amount); } \\
\text { manufacture and the creation of value chain (the consumption of energy, water, } \\
\text { wastes into the air, wastes utilization, the use of organic substances, renewable } \\
\text { energy share); workers and society (the number of workers, male and female part, } \\
\text { average amount of days of training and qualification rise, citizenship and corporate } \\
\text { training pay, charity, etc.) and the indexes in dynamics. }\end{array}$ \\
\hline 3. & Innovation support & $\begin{array}{l}\text { Innovation support presupposes the development of the conception of innovational } \\
\text { mobility. Companies participate in perspective startups achievements, develop new } \\
\text { technologies in the sphere of their activity. }\end{array}$ \\
\hline
\end{tabular}

2. Selection of indicators (factors), which characterize four aspects of CSR structure (Market place, Working place, Environment and Community). Indicators (factors) are going to be selected basing on studying CSR reports.

Table 3

\section{CSR working place elements}

\begin{tabular}{|l|l|l|}
\hline № & \multicolumn{1}{|c|}{ Elements } & \multicolumn{1}{c|}{ Descriptions of Elements } \\
\hline 1. & Security & $\begin{array}{l}\text { The issue of security is considered immensely by the companies, as they develop the } \\
\text { idea of safe and comfortable working conditions for their workers. The expenses on } \\
\text { the occupational health, fire safety, the number of workers participating in techno } \\
\text { and fire safety, modern equipment are represented in the reports. }\end{array}$ \\
\hline 2. & Human Rights & $\begin{array}{l}\text { Responsible and lawful behavior is the basis for corporate culture of a modern } \\
\text { enterprise as it creates the trust of clients and shareholders, partners and public, } \\
\text { ensuring a long-term perspective of activity development. }\end{array}$ \\
\hline 3. & $\begin{array}{l}\text { Sustainable } \\
\text { Professional } \\
\text { Development }\end{array}$ & $\begin{array}{l}\text { It means to produce the goals of the company which provides wide range of } \\
\text { possibilities for professional development of workers and the development of the } \\
\text { leaders of the company. The main goals of the sustainable professional development } \\
\text { are: the preparation of potential workers, the evaluation of workers' competence and } \\
\text { giving more skills, effective management of company mental resources of. }\end{array}$ \\
\hline
\end{tabular}


The Elements of Market place, Working place, Environment and Community are represented in the tabl. 2,3,4,5 respectively.

From practical point of view we presuppose the use of suggested elements in enterprise activity. It will allow to conclude about the efficiency of social interaction of enterprises and society. Inefficiency in reports and non-productive interaction may occur due to the lack of the mechanisms and the procedures of their building process.

Table 4

\section{CSR environment elements}

\begin{tabular}{|l|l|l|}
\hline № & \multicolumn{1}{|c|}{ Elements } & \multicolumn{1}{c|}{ Descriptions of Elements } \\
\hline 1. & Resources Efficiency & $\begin{array}{l}\text { To follow the aim to reduce the use of resources many companies apply innovational } \\
\text { technologies and modern energy efficient equipment which economizes energy and } \\
\text { presupposes the application alternative energy sources. }\end{array}$ \\
\hline 2. & $\begin{array}{l}\text { Teaching to Treat } \\
\text { Wastes and } \\
\text { Preventing from } \\
\text { Climate Changes }\end{array}$ & $\begin{array}{l}\text { The change of climate and resources deficiency is one of the biggest problems the society } \\
\text { faces today. To meet its demands we need to permanently reduce the release of CO2 and } \\
\text { lessen the amount of resources which are used during producing goods. Today, more and } \\
\text { more companies contribute to the implementation of social and ecological standards as } \\
\text { well as transparency and efficiency of the use of resources in the chain of delivery. Apart } \\
\text { from this, renewable energy while reducing CO2 release is becoming more and more } \\
\text { popular. It influences the solution to the problem under the climate change. }\end{array}$ \\
\hline 3. & $\begin{array}{l}\text { Product Safety and } \\
\text { Quality }\end{array}$ & $\begin{array}{l}\text { As providers of quality products for both national and foreign markets companies } \\
\text { must consider the safety and quality of products and services as their most important } \\
\text { task. As measures of safety and quality companies must provide the information } \\
\text { about product safe use and the risks when used inappropriately. Apart from this, the } \\
\text { logo of quality and safety should be on the package and approved by professional } \\
\text { and lawful evaluation. }\end{array}$ \\
\hline 4. & IT Efficiency & $\begin{array}{l}\text { Business environment today is characterized by a high level of complication and } \\
\text { uncertainty. This way, the question of fast adaptation to the changes of conditions } \\
\text { and necessary measures implementations of arises. The implementation of IT } \\
\text { measures will promote the automation of many production processes which will } \\
\text { serve the economizing of both financial and human resources. }\end{array}$ \\
\hline
\end{tabular}

Table 5

\section{CSR community elements}

\begin{tabular}{|l|lr|l|}
\hline № & \multicolumn{2}{|c|}{ Elements } & \multicolumn{1}{c|}{ Descriptions of Elements } \\
\hline 1. & $\begin{array}{l}\text { Interaction } \\
\text { Stakeholders }\end{array}$ & with & $\begin{array}{l}\text { Most stakeholders are clients, workers, shareholders and investors, creditors, } \\
\text { communities, state institutions, mass media, etc. At the same time the most important } \\
\text { methods for stakeholders and companies are questionnaires, inner private } \\
\text { communication, shareholders' meetings, the meetings with investors at the conferences } \\
\text { and discussions, public discussions, workshops, presentations and enterprise reports. }\end{array}$ \\
\hline 2. & $\begin{array}{l}\text { Investment into } \\
\text { Society } \\
\text { Partnership) }\end{array}$ & $\begin{array}{l}\text { Companies are using the strategy of social dialogue conduct with the society more } \\
\text { often, as the evaluation of their activity begins with social responsibility towards the } \\
\text { factors of inner and outer environment. }\end{array}$ \\
\hline
\end{tabular}

Suggested list of elements is not final and may change in practice, however, underlined elements allow their division into commonly used by national enterprises and those, which are applied by foreign enterprises at Ukrainian market in the process of social reporting, (see. tabl. 7,8,9,10).

3. Development of qualitative scale to evaluate the level of consideration of indicators (factors) in step two of the current method.

The suggested scale will enable to define the level of fullness of the interaction of enterprise and inner environment. In tabl. 6 we have represented the scale of quality of enterprise interaction with the elements of CSR responsibility.

4. Comparison of non-financial reports submitted by Ukrainian companies and international subsidiaries operating in Ukraine using indicators and scale developed at steps 2 and 3 of the current methodology. Finding out the differences in CSR aspects in the companies, which belong to Ukrainian nationals, and the international subsidiaries. 
Quality Scale of Enterprise Interaction with the Elements of CSR Responsibility

\begin{tabular}{|l|c|l|}
\hline$№$ & Evaluation Level & \multicolumn{1}{c|}{ Level Characteristics } \\
\hline 1. & Unsatisfactory & Company does not follow relevant aspects of CSR. \\
\hline 2. & Satisfactory & Company tries to positively meet the demands of certain aspects of CSR. \\
\hline 3. & Good & Company meets the demands of CSR. \\
\hline
\end{tabular}

The Analysis of the category "market place" provides the possibility to see that Ukrainian companies in their CSR reports apply the elements of the type "work results", whereas international subsidiaries which work for Ukrainian market, willingly represent "key sustainability indicators" and "innovation support" in their reports, apart from the elements mentioned previously (tabl. 6). Presenting such elements means getting familiarized with the innovations of enterprise, their expenses on the investigation and improvement of actual and new types of products. As a result, it will ensure the rise of potential clients and investors as well.

Table 7

Implementation of CSR market place elements at international subsidiaries and Ukrainian companies

\begin{tabular}{|c|c|c|c|}
\hline № & Elements & Companies & $\begin{array}{l}\text { Implementation of CSR elements at the particular } \\
\text { companies }\end{array}$ \\
\hline \multicolumn{4}{|c|}{ International subsidiaries } \\
\hline 1. & $\begin{array}{l}\text { Key sustainability } \\
\text { indicators }\end{array}$ & $\begin{array}{l}\text { BMW Group, } \\
\text { Hewlett-Packard's } \\
\text { Ukraine }\end{array}$ & $\begin{array}{l}\text { BMW Group in their social reports presents the range of } \\
\text { indexes to characterize their activity: research and } \\
\text { development expenditure, regional distribution of BMW } \\
\text { Group purchase volumes in } 2017 \text {, BMW Group personnel } \\
\text { costs per employee, public sector grants: public subsidies in } \\
\text { the form of reduced taxes on assets and consumption-based } \\
\text { taxes, coverage rate of the production locations with quality } \\
\text { management systems, total energy consumption, investment } \\
\text { in environmental protection. }\end{array}$ \\
\hline 2. & Innovation support & $\begin{array}{l}\text { Honda Global, } \\
\text { Hewlett-Packard's, } \\
\text { Adidas Group }\end{array}$ & $\begin{array}{l}\text { Honda Global is a world innovations leader. The } \\
\text { implementation of new technologies promotes more } \\
\text { segments at the market. }\end{array}$ \\
\hline \multicolumn{4}{|c|}{ Ukrainian Companies } \\
\hline 3. & $\begin{array}{l}\text { Work Results( } \\
\text { Financial Indexes) }\end{array}$ & $\begin{array}{lr}\text { SoloMia, } & \\
\text { Myronivskii } & \text { Bread } \\
\text { Product } & \text { (MBP), } \\
\text { Biofarma } & \end{array}$ & $\begin{array}{l}\text { Biofarma, while making their social report, represents the } \\
\text { results of their work through the financial indexes, such as: } \\
\text { income, expenses. The expenses on social responsibility is a } \\
\text { very important financial index which enables analyzing } \\
\text { enterprise activity in the interaction of enterprise and society. }\end{array}$ \\
\hline
\end{tabular}

According to the division of quality scale of the companies and CSR responsibility interaction (see. tabl. 6), the development of CSR report by Ukrainian companies may be evaluated as "satisfactory". It means that Ukrainian companies try to follow the experience of companies and society interaction from abroad. They donate to many charity events. Let us consider, for instance, "Myronivskii Bread Product", it supports the development of the community, infrastructure projects (road repair "Harvested country", "Oryl-leader", "Agro-S", "Agrokryazh" etc, educational projects (the purchase of computers, primary educational establishments repair), culture projects (creative circles support), sport support projects (contests, football tournaments) and others.

If compare the category "working place", we can observe that while developing CSR report, national companies apply the same elements as do international subsidiaries ones, which work at Ukrainian market. In this category, a crucial part belongs to workers' efficiency rise. The trainings to improve workers' competence are becoming more and more popular. The training is permanent and companies is open to hire more professionals. Thereby, enterprise presupposes its care about its staff and this way it receives rewards in the face of productivity and income rise. 
Considering similar scales of companies interaction with the elements of CSR responsibility evaluation (see. tabl. 6), Ukrainian enterprise activity may be evaluated as "good". According to the category "working place", Ukrainian companies are on the same level with the international subsidiaries which work at Ukrainian market. A great importance is attached to professional development of workers as financial rise of the company mostly depends on this factor.

Table 8

Implementation of CSR working place elements at international subsidiaries and Ukrainian companies

\begin{tabular}{|c|c|c|c|}
\hline № & Elements & Companies & $\begin{array}{l}\text { Implementation of CSR elements at the particular } \\
\text { companies }\end{array}$ \\
\hline \multicolumn{4}{|c|}{ Ukrainian Companies } \\
\hline 1. & $\begin{array}{l}\text { Sustainable } \\
\text { Professional } \\
\text { Development }\end{array}$ & Soft Serve & $\begin{array}{l}\text { SoftServe is one of the first in Ukraine who established } \\
\text { their own corporate SoftServe University, which is an } \\
\text { efficient tool to provide business goals of the company } \\
\text { and the environment which provides good prospects for } \\
\text { the staff efficiency rise and leadership formation. The } \\
\text { main goals of stable professional development are: } \\
\text { training of perspective workers, knowledge level } \\
\text { evaluation, certain competence development, effective } \\
\text { management company human resources. }\end{array}$ \\
\hline 2. & Safety & $\begin{array}{l}\text { "Interhim", } \\
\text { "Biofarma", Airline } \\
\text { Company } \\
\text { "International Airlines } \\
\text { of Ukraine" }\end{array}$ & $\begin{array}{l}\text { Airline Company "International Airlines of Ukraine" is } \\
\text { one of the carriers who have successfully experienced the } \\
\text { system of evaluation of operational management and } \\
\text { control of airline company according to the program of } \\
\text { audit and safety IATA(IOSA). }\end{array}$ \\
\hline
\end{tabular}

Table 9

Implementation of CSR environment elements at international subsidiaries and Ukrainian companies

\begin{tabular}{|c|c|c|c|}
\hline № & Elements & Companies & $\begin{array}{l}\text { Implementation of CSR elements at the particular } \\
\text { companies }\end{array}$ \\
\hline \multicolumn{4}{|c|}{ International subsidiaries } \\
\hline 1. & Product safety and quality & $\begin{array}{l}\text { McDonald's } \\
\text { Corporation, Hewlett- } \\
\text { Packard's, } \quad \text { Adidas } \\
\text { Group, Coca-Cola } \\
\text { Україна }\end{array}$ & $\begin{array}{l}\text { As a global business operating, the Adidas Group has } \\
\text { a responsibility to look after the natural environment, } \\
\text { both for people today and in the future. Within the } \\
\text { lifecycle of its products there are two points in the } \\
\text { design and development process where a significant } \\
\text { difference to the company's environmental footprint } \\
\text { can be made. The first is in improving the materials } \\
\text { that go into the products, and the second is in } \\
\text { tackling pollution in factories. Ensuring product } \\
\text { safety is also an imperative for product management, } \\
\text { development and manufacturing processes. }\end{array}$ \\
\hline 2. & IT Efficiency & $\begin{array}{l}\text { Sturbucks } \\
\text { Corporation, Hewlett- } \\
\text { Packard's }\end{array}$ & $\begin{array}{l}\text { Hewlett-Packard's is one of many companies who } \\
\text { simplify the processes of productivity with the help } \\
\text { of IT technologies. Sites development allows } \\
\text { economizing on both financial and human resources. }\end{array}$ \\
\hline \multicolumn{4}{|c|}{ Ukrainian Companies } \\
\hline 3. & Resources Efficiency & $\begin{array}{l}\text { FerrexpoGroup, } \\
\text { Agrogeneration, } \\
\text { DTEK, Nova Poshta }\end{array}$ & $\begin{array}{l}\text { DTEK serves under the conditions of energy-service } \\
\text { contracts and performance-contracts. DTESKO also } \\
\text { fulfills energy audits, develops and realizes complex } \\
\text { orders on energy resources economy. The company } \\
\text { also promotes finance to realize energy efficient } \\
\text { projects for clients and teaches clients the basics of } \\
\text { energy management implementation systems. }\end{array}$ \\
\hline
\end{tabular}




\section{Г. В. Лема, І. Б. Олексів, В. Ю. Харчук, Т. Ю. Лісович}

The category "environment" provides the possibility to see how efficiently the companies use the resources in the process of producing goods. Ukrainian companies attach importance to the elements of "resource efficiency", as the use of eco innovations promotes clear production and the economy of material and human resources. However, national companies should borrow such elements as "product safety and quality" and "IT efficiency" from the international subsidiaries. Previously mentioned elements provide time economy and raise the image of a company.

According to the qualitative scale of evaluation, Ukrainian companies get "satisfactory" level. Ukrainian companies try to apply the experience of international subsidiaries, which work at Ukrainian market, however to receive "good" level and also improve a working process they need to learn more about international standards. Ukrainian company - Nova Poshta - in 2016 began to use electric cars with the aim of economy of the resources. "Nova Poshta" claims that the use of electric vehicles is an innovation approach and socially aware business. However, if consider such elements as product safety, the company "Nova Poshta" does not meet the standards of international subsidiaries since while delivering, there are cases of damaging goods or incorrect delivery, which eventually causes client's discomfort. However, "Nova Poshta" takes every measure to solve the problems mentioned previously.

Table 10

Implementation of CSR community elements at international subsidiaries and Ukrainian companies

\begin{tabular}{|c|c|c|c|}
\hline № & Elements & Companies & $\begin{array}{l}\text { Implementation of CSR elements at the particular } \\
\text { companies }\end{array}$ \\
\hline \multicolumn{4}{|c|}{ Ukrainian Companies } \\
\hline 1. & $\begin{array}{l}\text { The Interaction with } \\
\text { Stakeholders }\end{array}$ & $\begin{array}{l}\text { Ltd. "Ukrainian Retail", } \\
\text { Myroniskii Bread Product }\end{array}$ & $\begin{array}{l}\text { In the process of interaction with stakeholders, Ltd. } \\
\text { "Ukrainian Retail" applies public reports on the } \\
\text { enterprise activity, meetings with investors, public } \\
\text { speaking, etc.. }\end{array}$ \\
\hline 2. & $\begin{array}{lr}\text { Investment } & \text { into } \\
\text { Society } & \text { (Social } \\
\text { Partnership) } & \end{array}$ & $\begin{array}{l}\text { TSV Company, Roshen, } \\
\text { Myronivskii BreadProduct } \\
\text { (MBP) }\end{array}$ & $\begin{array}{l}\text { At MBP enterprises different projects are realized, } \\
\text { including community support, infrastructure projects } \\
\text { (road repair, parks reconstructions, bores); } \\
\text { educational projects (the purchase of computers, } \\
\text { primary schools repair); culture projects (creative } \\
\text { circles support), sports projects support (contests, } \\
\text { tournaments), etc. }\end{array}$ \\
\hline
\end{tabular}

According to a quality scale of evaluation, Ukrainian companies may be evaluated as "good" if considered the interaction of company with the elements of CSR responsibility of the report development (see. tabl. 6). Ukrainian companies eagerly cooperate with stakeholders and society. Let us, for instance observe the company "TSO Company" as an example of social partnership. Its factors of success are responsibility for clients, co-workers, partners and charity. As a charity work, the company supplies necessary goods to educational establishments. Apart from this, TSO Company conducts the contests and provides the prizes which are company products. Any educational establishment of Ukraine may take part in such contests if it keeps to the demands of the competition.

So, national companies, while reporting on their activity, use such elements as interaction with stakeholders (Ltd. "Ukrainian Retail", Myronivskii Bread Product), safety (Interhim), resource efficiency (Agrogeneration, DTEK), the interaction with society (Roshen), etc. However, we can rarely come across such elements as "sustainable professional development". International subsidiaries (McDonald's, Nestle Ukraine) use this elements to show the level of professional development of their workers, provide them with proper training conditions certification with the help of hiring proper professionals. It technologies application is an important elements which is widely used by international subsidiaries (Sturbucks Corporation, Hewlett-Packard's), as it promotes a quick data processing and saving. 


\section{Conclusions}

Taking into account the distribution of elements according to the categories of market place, working place, environment, community will promote further development of CSR reports. In case of company meeting the demands of this structure, the evaluation of their activity will largely improve and will also promote the development of CSR reports. If companies keep to the structure, it will make the evaluation of their activity easier and will promote specific criteria of such evaluation efficiency.

The analysis of CSR reports of companies provides the possibility of developing the conclusions that public reports provide the transparency of its management. The data provided in such reports describes practically all the hands of social interaction of company and society in general. Apart from this, the division of elements used in CSR reports will enable national companies analyze their own activity and the possibility of reflection of new elements while developing further reports.

\section{References}

1. Tamara Vlastelica, Slavica Cicvaric Kostic, Milan Okanovic, Milos Milosavljevic, (2018). JEEMS How Corporate Social Responsibility Affects Corporate Reputation: Evidence from an Emerging Market.

2. Cătălin Nicolae Albu, Cagnur Balsari and Joanna Krasodomska, (2016). Accounting and Management Information Systems Introduction to the Special issue on Corporate Social Reporting in Central and Eastern Europe.

3. Yury Blagov and Anastasia Petrova-Savchenko, (2012). Corporate Governance, Corporate philanthropy in Russia: evidence from a national awards competition.

4. Heather Elms (2006), International Journal of Emerging, Markets, Corporate (and stakeholder) responsibility in Central and Eastern Europe.

5. Olivier Furrer, Carolyn P. Egri, (2010). Management International Review, Attitudes toward Corporate Responsibilities in Western Europe and in Central and East Europe.

6. Liliana Nicoleta Grigore and Camelia Candidatu (2009). Romanian Economic and Business Review, The perception and role of corporate social responsibility in Central and Eastern Europe.

7. Strouhal, J., Gurvitš, N., Nikitina-Kalamäe, M., Startseva, E., (2015). Central European Business Review, Finding the Link between CSR Reporting and Corporate Financial Performance: Evidence on Czech and Estonian Listed Companies.

8. Iankova, Elena A. (2008). The Journal of Corporate Citizenship; From Corporate Paternalism to Corporate Social Responsibility in Post-Communist Europe.

9. Jozica KNEZ-RIEDL (2004). FROM THE ENVIRONMENTAL RESPONSIBILITY OF SLOVENIAN SMES TO THEIR CORPORATE SOCIAL RESPONSIBILITY (CSR).

10. Beatrix Ransburg, Mária Vágási (2007). Social and Management Sciences, Concepts and standards for the corporate internalization of sustainable development.

11. Rogowski W. (2013). Organization and Management Examples of CSR Related Activities at Polish Companies.

12. Neda Vitezić (2011). Correlation between social responsibility and efficient performance 424 Zb. rad. Ekon. fak. Rij.

13. Carroll, A.B. (1979). A three-dimensional conceptual model of corporate social performance. Academy of Management Review, 4, 497-505.

14. Carroll, A. B. (1991). The Pyramid of Corporate Social Responsibility: Toward the Moral Management of Organizational Stakeholders Business Horizons /July-August 1991.

15. $h t t p: / / s v b . u a /$ report/2017/mhp

16. http://svb.ua/reports/novaposhta-2017

17. http://svb.ua/report/galnaftogaz-2016

18. http://svb.ua/reports/dtek/2016

19. http://svb.ua/report/ernst-and-younge-ukraine/2015-2016

20. http://svb.ua/reports/nestle-ukraine-2016

21. http://svb.ua/reports/zvit-zi-stalogo-rozvitku-koncernu-galnaftogaz-za-2015-rik

22. http://svb.ua/sites/default/files/softserve_social_report_2015-2016_ukr.pdf

23. https://www.bmwgroup.com

24. http://tso.com.ua

25. https://corporate.mcdonalds.com/content/dam/gwscorp/scale-for-good/ESG_Reporting_Website_Archive_ 2016.pdf 
Г.В. Лема, І.Б. Олексів, В.Ю. Харчук, Т.Ю. Лісович Національний університет "Львівська політехніка"

\section{КОРПОРАТИВНА СОЦІАЛЬНА ВІДПОВІДАЛЬНІСТЬ В КРАЇНАХ, ЩО РОЗВИВАЮТЬСЯ: УКРАЇНСЬКИЙ АСПЕКТ}

\section{(С Г.В. Лема, І.Б. Олексів, В.Ю. Харчук, Т.Ю. Лісович, 2019}

На сьогодні значна кількість підприємств обирають курс розвитку своєї діяльності шляхом залучення широкого кола стейхолдерів. В такому випадку, стратегія розвитку підприємства часто побудована шляхом прийняття принципів CSR. CSR вітчизняних підприсмств с важливим проявом взаємодії соціальних та економічних відносин. Серед українських підприємств дедалі популярнішим є оприлюднення нефінансового звіту про CSR. Такий звіт дає можливість ознайомитися стейкхолдерам про взаємодію підприємства із соціальними заходами. Одним із недоліків формування звіту про корпоративно-соціальну відповідальність підприсмства с відсутність чіткої структури. Окрім того, на сьогодні відсутні чіткі показники чи положення 3 оцінювання корпоративно-соціальної відповідальності підприсмств. Таким чином, більшість підприсмств складають звіти у довільній формі. Відповідно існують і ускладнення в аналізуванні соціальних звітів, оскільки вони не с обов'язковими. Отже, важливим завданням в процесі дослідження корпоративно-соціальної відповідальності вітчизняних підприємств с формування методичних рекомендацій, які міститимуть критерії, показники та особливості оцінювання. Аналізування корпоративно-соціальних звітів вітчизняних та закордонних підприсмств, які працюють на ринку України дає можливість виділити основні категорії CSR: ринок, робоче місце, навколишнс середовище та комунікації. Відповідно, кожна із категорій включас характеристики за якими с можливість порівняння соціальних звітів вище вказаних підприємств, а відтак і оприлюднення висновків про ефективність формування CSR. Перевагами участі підприсмств у соціальній відповідальності є можливість розширення ринків збуту, можливість економії витрат при використанні у виробництві екологічного устаткування, забезпечення належних робочих місць тощо. Таким чином, формування соціально-корпоративних звітів у цілому виступають цінним ресурсом при дослідженні діяльності підприємства та його взаємодії із суспільством.

Ключові слова: корпоративно-соціальна відповідальність, соціальний звіт підприємств, елементи корпоративно-соціальної відповідальності. 